\title{
ARTICULATION: A PROPOSAL TO MAXIMIZE EXCELLENCE IN COLLEGIATE AVIATION EDUCATION
}

\author{
Dr. Henry F. Hartsell \\ Western Oklahoma State College \\ Dr. Brent D. Bowen \\ Wichita State University
}

\begin{abstract}
The purpose of this study was to gain insight into articulation and transter arrangements between two-year and four-year higher education institutions. As a means towards this end, a thorough review of literature supporting articulation was conducted. A presupposition on which this study focused was that aviation associate degrees are not intertwined with baccalaureate degree programs. This obstacle places a burden on students' abilities to complete both the associate and baccalaureate degrees within an economical four-year time period. Few institutions have developed articulation agreements for aviation programs with other institutions. A content analysis methodology was applied to the catalogs and schedules of all institutions of higher education in Oklahoma. Potential opportunities for articulation were examined and the results presented. Recommendations for action toward this goal were proposed.
\end{abstract}

\section{Introduction}

As the United States prepared for war in the late 1930's, colleges became an important part of flight training under the Civilian Pilot Training Program initiated by Congress in 1939. Under this program, colleges and universities taught many pilots to fly as the Nation prepared for and entered World War II. Following World War II, numerous colleges and universities provided aviation courses and programs for many returning veterans. Later, a few higher education institutions offered aviation programs, but most of the flight training shifted to non-college flight schools during the mid-twentieth century. Once again, many colleges and universities are offering aviation.

The advantages to students who might efficiently transfer from a college with low-cost flight training to a university with an aviation baccalaureate program are obvious. For example, the tuition cost of lower-division courses at Oklahoma two-year colleges in the fall of 1990 was $\$ 27.30$ per hour versus $\$ 47.05$ per hour at Oklahoma four-year institutions. The tuition savings alone would amount to $\$ 296.25$ per semester. The flight training costs might be less as well. For example, the cost for flight instruction and airplane rental for training through the commercial pilot certificate with an instrument rating at one two-year college was $\$ 6,340$ versus $\$ 10,250$ at a four-year university. This example is potentially accurate for numerous other states.

In many instances, aviation associate degrees do not intertwine with the baccalaureate degree programs to allow students to complete both the associate and baccalaureate degree requirements within a four-year period. For example, in Oklahoma a student who has graduated from a two-year college and enters an Oklahoma four-year university is sometimes treated as an entering freshman for the first semester at the university. The two-year college graduate is not credited the status and awarded privileges of other juniors who have previously attended the university. These students are not only excluded from such things as purchasing preseason football tickets, but also may not have the 
opportunity to enroll in the most desirable class times because previously enrolled university students may be allowed to enroll before transferring students. These culturally shocking changes could be alleviated through more effective articulation.

The purpose of this paper is to determine ways to improve the articulation and transfer for aviation students graduating from two-year colleges and continuing toward aviation baccalaureate degrees. Another purpose of this effort is to explore ways of connecting the two-year and four-year programs to allow the aviation student to complete both associate and baccalaureate degrees in an economical four-year time period.

\section{Articulation: a Perspective}

Since the beginning of the junior college movement early in the twentieth century, transfers of students from two-year to four-year institutions of higher education have been significant. Most of these transfer arrangements have been informal. The literature concerning articulation and transfer became prominent in the 1960's as higher education expanded to meet the exploding demand. Transfer and articulation continued to appear in the literature frequently through the 1980's and into the last decade of the twentieth century. Collegiate aviation education is experiencing new support for articulation with transter agreements emphasized by the FAA's Airway Science Program. As higher education continues to become more competitive, articulation will become vital to institutional survival in the 1990's and beyond.

In The Junior College: Progress and Prospects (1960), Dr. Leland L. Medsker reported the results of a study of the 1952 entering class in 63 cooperating two-year colleges that enrolled 17,627 students in September, 1952. Medsker found that a median of $35 \%$ graduated, $33 \%$ transferred, and $56 \%$ of those who graduated, transferred. Medsker studied the performance and retention of the transfer students. In general, the transfer students did somewhat less well than the native students in the first term after transfer. By the end of the senior year, however, the transfer student's grades closely approached the native student grades and tended to have not more than a 0.3 grade point differential. The retention rates for transfer students was markedly lower than for native students. The percentage of students receiving baccalaureate degrees at the end of the second year after transfer was much lower than for the native students. Only $40 \%$ of the transferring students received baccalaureate degrees by the end of four years after they entered junior college. Institutions reported a greater number of transfer students who completed degrees later, however.

Dorothy M. Knoell and Leland L. Medsker (1964) reported the results of their research of the performance of transfer students in $\mathbf{4 3}$ colleges and universities in Factors Affecting Performance of Transfer Students From Iwo- to Four-Year Colleges. Located in ten states selected on the basis of geography and type of statewide control, these colleges and universities were divided into five categories: major universities, teachers' colleges, other state colleges and universities, private colleges, and technical schools. Junior college students who transferred in 1960 were included in the study group as well as a sample of native students who graduated in 1962 which were used for comparison.

Knoell and Medsker (1964) found that $45 \%$ of the students who transferred after two years in junior colleges earned baccalaureate degrees about two years later. Another $31 \%$ were still enrolled at the end of two years and eligible to enroll in the next term. After transfer, the average grade-point drop was 0.3 in the first term. However, the averages for the transfer students increased each semester from 2.27 for the first semester to 2.68 for the fourth semester after transfer. The transfer students earned higher averages than the native students in lower division, but the native students earned higher averages in the upper division (Knoell \& Medsker, 1964, pp. 174-181). 
Nearly half of the students lost no credit in transferring from junior college. About $20 \%$ lost the equivalent of a three-hour course. Less than $10 \%$ lost substantial amounts of credit, such as a semester. The students probability of graduating on time was significantly related to the choice of major and the choice of four-year college. Students majoring in teacher education had a high incidence of graduating on time while those majoring in engineering had high attrition and a low probability of graduating in two years. Transferring students were just as efficient as native students in terms of the number of semesters attended and units earned toward the baccalaureate degree requirements. However, higher percentages of native students maintained continuous enrollment through graduation. (Knoell \& Medsker, 1964, pp.174-181).

Knoell and Medsker (1964) found that practices in awarding credit for junior college courses appeared to be fairly arbitrary and varied randomly among the colleges. In general, approximately one-half of the baccalaureate degree requirements as well as only the lower division courses would be considered for transfer credit. A better rationale is needed. There is gradual obliteration of the distinction between upper and lower division courses. Considerable amounts of advanced standing credit are awarded to entering freshmen. The findings imply that a rationale for awarding transfer credit should be based on the principle of what is in the best interest of the student, rather than an arbitrary division of responsibility between the two-year and four-year institutions (Knoell \& Medsker, 1964, p. 183).

Frederick C. Kintzer, in The Multidimensional Problem of Articulation and Transfer (1983), stressed that the transfer of students can no longer be considered only in the terms of linear progression from community colleges to four-year institutions. He defined transfer as the movement of students and their academic credits from one school to another. Kintzer then defined articulation as services for transfer students and identified six categories of transfer students: articulated vertical; reverse (from a four- to a two-year college); vocational; lateral; international (foreign); and nontraditional (drop-outs, industry, government, and experimental learning). Kintzer suggested that further research is needed to develop uniform identification and counting systems.

Karen Doyle Walton, in "Articulation: Transfer Agreements, Minimum Grades Acceptable on Transfer Courses, and Transferability of Associate Degrees," published in the Community/Junior College Quarterly in 1984, surveyed 1,000 two- and four-year institutions to examine transfer agreements and transferability of associate degrees in 1982. Articulation agreement was defined as: "A specific written agreement between two institutions (frequently between a two-year institution and a four-year institution) whereby student transfer is facilitated (and often guaranteed). The agreement assures the transferability of credits taken at the first institution into a program or course of study at the receiving institution." (Walton, 1984, p. 171). The majority $(57.7 \%)$ of all institutions had no written agreement about transfer. Only $20.7 \%$ of the responding four-year institutions have articulation agreements with two-year colleges, and $20.1 \%$ have course transfer lists. Walton found that institutions with higher percentages of transfer agreements to be public rather than private colleges, two-year rather than four-year, large, and located in the West.

Walton (1984) also found that the majority $(68.1 \%)$ of the four-year institutions do not accept the Associate of Arts and the Associate of Applied Science degrees without evaluating courses individually. Of the four-year institutions that accept associate degrees without evaluating courses individually, $16.5 \%$ accept both the Associate of Arts and the Associate of Applied Science, 14.2\% accept the Associate of Arts only, and $1.1 \%$ accept the Associate of Applied Science only.

In the Anticulation/Transfer Phenomenon: Patterns and Directions (1985), Frederick C. Kintzer and James $\mathrm{L}$. Wattenbarger defined articulation as "the generic term referring to the entire range of processes and relationships involved in the systematic movement of students inter-institutionally and inter-segmentally throughout postsecondary education." (Kintzer \& Wattenbarger, 1985, p. iii). They defined, "Transfer-- 
the mechanics of credit, course, and curriculum exchange--is one of the processes." (Kintzer \& Wattenbarger, 1985, p.iii). Transfers from community colleges to baccalaureate degree programs have been declining in the last decade. Reasons include deteriorating articulation services for transfers, competition for minorities, lack of uniformity of credit acceptance in multiversities, and shift from academic to occupation career interests. Transfer students will not regain a preeminent role until 2000 . The proportion of transfer students had slipped from $66 \%$ to $43 \%$ by 1973 . Of all credit students, $63 \%$ are in occupational programs. (Kintzer \& Wattenbarger, 1985, pp. 1-3).

Kintzer and Wattenbarger (1985) reported articulation trends across the nation. In Illinois, associate in arts and associate in science graduates performed better than native students in retention, baccalaureate degree completion, and grade point average. The Oklahoma State System Plan was discussed and reported to require 33 hours of general education. They wrote, "Although occupational education is not directly mentioned in the agreement, graduates of community college career programs are encouraged to include major courses to meet baccalaureate requirements." (Kintzer \& Wattenbarger, 1985, p. 31). Courses classified as junior level yet open to sophomores in Oklahoma four-year institutions may be transferred from community colleges. The community colleges are a part of the university system in Kentucky and Nevada. Two-plus-two programs are used in Oregon and Texas. In North Carolina, the bachelor of technology degree provides for exchanges between the two-year and four-year schools. Upper-level universities are found in 11 states. There are a total of 25 , and more than one-half are located in Texas. The number of states formulating articulation and/or transfer policies has not increased substantially in the last fifteen years. Some state legislatures have required that transfer agreements be made.

Frederick C. Kintzer evaluated statewide articulation and transfer agreements in 1985. He defined articulation as referring, "... to services provided students transferring from high schools-- to community colleges-- to universities and the reverse, and laterally throughout higher education." (Kintzer, 1985, p. 1). He defined transfer as, "... course and credit equivalency exchanges." (Kintzer, 1985, p. 1). His focus was on a taxonomy of types of agreements.

The original taxonomy of 1972 contained 22 states and this was expanded to 37 states in his taxonomy of 1976. Kintzer's study of 1985 targeted 21 states where statewide articulation and transfer had changed in character and where multiple types had appeared. Each of the taxonomies was divided into four types of agreements (Kintzer, 1985).

The group of states with Formal and Legal-Based Guidelines and Policies traced their authority to the state constitution, legislature, education code, or master plan. The states in this group that was the focus of Kintzer's research in 1985 were Florida, Illinois, Massachusetts, Nevada, Rhode Island, South Carolina, and Washington. Associate degree completion was the basic qualification for transfer although credits for individual courses were usually accepted. Articulation services are included, and general education requirements are presented in detail. (Kintzer, 1985).

The second group includes states that have State System Policies. The states in this group that were the focus of Kintzer's research in 1985 were Arizona, Hawaii, Maryland, New Jersey, New York, Oklahoma, Virginia, and Wyoming. The State System Policies emphasized credit transfer, show less attention to articulation services, place responsibility in a state official, often in the university system, and give substantial power to the responsible agency. Kintzer included Oklahoma in the group of States with this type of agreement.

The third group of states have Voluntary Agreements Between Institutions or Within States. Kintzer focused his 1985 research on California and Pennsylvania. In this group, decisions were reached as 
transfer cases arise. The small number of transfer applicants in some states postpones the need for formalized agreements. About one-half of the 50 states were included in this group.

The fourth group included States Specializing in Vocational-Technical Credit Transfer. Kintzer focused his 1985 research on Michigan, North Carolina, Ohio, and Oregon in this group. Included in the group are the long-standing technical institute/senior college-university baccalaureate packages. The newest are four-year programs that tie the final two Tech Prep years in high school with the associate degree years in two-year colleges. Many states had multiple types of statewide agreements and would be listed with more than one group. (Kintzer, 1985, pp. 3-5).

The first statewide articulation agreement, the Florida Formal Agreement Plan was approved in 1965 and reconfirmed in 1971. The original Florida plan was significantly changed in 1985 by adding the following: a statewide common course numbering system; a common calendar; College-level Academic Skills Test; and a common entry test. The Oklahoma Plan became operational in 1977. A recent change was that senior institutions may require additional general education to graduate. However, this must be upper-division course work. Another provision of the Oklahoma Plan provided that, "courses classified as junior-level yet open to sophomores at senior institutions even though taught at a two-year college as sophomore-level courses, are transferrable as satisfying that part of the content area requirement." (Kintzer, 1985, p. 29). This was a major breakthrough for community college education. This indicated that two-year college faculty have integrity in terms of degree application of courses, at least in Oklahoma.

Dr. Louis W. Bender, a consultant from Florida State University, in Iransfer and Articulation Among the Public Institutions of Higher Education in New Jersey (1987) wrote that less than $50 \%$ of county community college graduates who transfer to the New Jersey state colleges have all credits accepted. He found that only $25 \%$ of all undergraduates transfers at state colleges are at the junior or higher class level. He concluded that the Full-Faith-and-Credit Policy, upon which the study focused, "is more myth than reality." (Bender, 1987, p. iii).

Bender (1987) found a noteworthy exception in the New Jersey Institute of Technology (NJIT) which recognizes associate degree graduates as juniors, and has a program to orient transfers. NJIT faculty taught transition courses on county college campuses as a part of the last year of the associate degree programs.

Bender (1987) made several recommendations in his report to the New Jersey Chancellor of Higher Education. He recommended a $2+2$ program, and services comparable to lower division entry including recruitment, admissions, orientation, scholarship incentives, and advisement. He also recommended a computerized data bank, and an official articulation/transfer office at each college. Bender stated that, "The community colleges should strengthen their capability to provide students with accurate information on transferability of all of their degree programs, including clarification of the AAS as an applied/practical education program that only should interface with baccalaureate level applied/practical programs." (Bender, 1987, p. ix).

Jim Palmer, in Bolstering the Cemmunity College Transfer Function (1986), viewed transfer as a multidimensional problem of student flow from high school through the baccalaureate level, not simply a matter of credit articulation. He would focus on the transferability of competencies as well as credits. This could be accomplished by the proper academic rigor and expected competencies of students; temporary appointment of community college faculty as visiting instructors at four-year institutions to reacquaint them with university students and the rigor at the upper division level; or by exit tests for transfer students. Problem areas that remain include identifying potential transfer students, tracking them, and providing information for students. 
In "2-year institutions under pressure to ease transfers," published in the Chronicle of Higher Education on February 7, 1990, Beverly T. Watkins stated that streamlining the transfer process is critical to increasing the achievement of minority students. One-third of the students enrolled in two-year colleges plan to continue, but no more than one-quarter transfer. Transferring is a tough bureaucratic task for students. (Watkins, p. A37).

Watkins (1990) reported that currently the National Academic Achievement and Transfer Project at the American Council on Education is striving to improve articulation. The project will try to make lower division offerings compatible at twenty-four pairs of two-year and four-year colleges so that community college students can transfer to baccalaureate institutions without having to repeat courses. This is a $\$ 1.2$ million project with support from the Ford Foundation.

Watkins (1990) reported other efforts to improve transfers. The United Negro College Fund has just completed a pilot project with 16 universities and 10 community colleges in the South to increase the number of black students who complete baccalaureate degrees. A second project is undenway with five universities and seven community colleges. Elsewhere, the National Effective Transfer Consortium of 28 community colleges is conducting research on transfer practices. Another project designed to show that disadvantaged students can get a liberal arts education and a baccalaureate degree, "Exploring Transfer," takes about 50 black and Hispanic students from the City University of New York's Fiorello H. La Guardia Community College to participate in a summer program at Vassar College.

\section{Articulation and the Airway Science Program}

The Airway Science Curriculum is designed as a four year baccalaureate program. The Airway Science Curriculum Committee encourages community colleges to offer courses within the airway science curriculum that are considered lower division courses. Community colleges are encouraged to make articulation agreements with four-year institutions having Airway Science Curricula. Community college students should be advised to take only courses considered to be lower division by the four-year institution. These students should then be encouraged to complete an associate degree although this will usually not be in aviation, but rather an associate in arts, associate in science, or general studies. The community college student should be advised to make certain that he/she will be able to meet the four-year institution's residency requirement, which may be approximately one-half of the degree requirements. (Curriculum)

Course titles vary considerably among colleges. The University Aviation Association has published the college Aviation Accreditation Guidelines. (UAA, 1976). The guidelines recommend course titles and semester hours but do not recommend which courses should be upper division level.

The Airway Science Curriculum Guidelines For Community Colleges list 70 semester hours of lower division core courses. Among these courses are Introduction to Aeronautics (may be Private Pilot Ground School), Air Traffic Control, and the National Airspace System. Among the lower division courses from the area of concentration in Aircraft Systems Management are Private Pilot Certification (Ground \& Flight), Commercial Pilot Certification (Ground \& Flight), Instrument Rating (Ground \& Flight), Meteorology, Air Transportation, and one elective for a total of 24 hours in this area of concentration. Air Transportation is also included among the lower division courses in the Airway Science Management concentration. (Curriculum). 


\section{Recommendations for Action}

(1) The Oklahoma State Regents should revise the articulation policy to allow graduates of two-year aviation programs to transfer the entire general education requirements for lower division. Thus, institutions should coordinate general education requirements.

(2) The State Regents should approve two-year aviation programs as associate in science degree programs as well as associate in applied science degree programs. The State Regents' policy would also have to delete the requirement that the majority of the course work in addition to the required 37 hours of general education should be in courses classified as liberal arts and sciences. These policy changes could place the two-year associate degree programs within the state articulation agreement.

(3) Universities with aviation baccalaureate degree programs should change more aviation courses to lower division level. This should enhance articulation and transfer possibilities between two-year and four-year aviation programs, and would likely reduce student costs. This could only be accomplished if the number of upper division hours exceed the minimum requirement.

(4) Aviation program heads and coordinators should meet annually to discuss articulation and transfer among Oklahoma colleges and universities. The author will attempt to coordinate such a meeting in central Oklahoma in the fall of 1991.

(5) Aviation program heads and coordinators should take action to standardize course titles and numbers.

(6) Aviation program heads should review this study and make recommendations on how to improve articulation and transfer to the author.

(7) Universities should assign graduates of two-year aviation programs who are transferring to baccalaureate aviation programs directly to the aviation department of universities. Additionally, transferring graduates should be immediately assigned to faculty advisors who are members of the aviation departments.

\section{FUTURE PROMISE FOR ARTICULATION}

In 1988, Dale Parnell stated, "Core Curriculum will be as valid for technical education students as it is for the liberal arts students" in The Future of the Cemmunity College (Parnell, p. 7). He also warned that university professors must accept the advantages of allowing specialized training to be conducted along with the lower division core curriculum rather than after the lower division experience. Parnell predicted that, "By 2010 every state will have developed coherent collegiate student transfer agreements, coordinated academic calendars, common course numbering, and sequential curriculum planning. The fabric of schools, community colleges, and universities will look much more like a seamless garment than it does today." (Parnell, 1988, p. 11),

\section{Summary}

This study attempted to determine the nature of the curriculum for each of the collegiate aviation programs in Oklahoma. Catalogs and schedules were analyzed to determine the contents of each program. A survey was conducted to confirm data obtained from published sources, and to gain insight into articulation and transfer arrangements between the two-year and the four-year higher education institutions. The Oklahoma State Regents of Higher Education policies were researched to discover guidance and restrictions for articulation between aviation programs. 


\section{References}

Airway science curriculum committee curriculum quidelines for community colleges. (No Date). Washington, D.C.: Federal Aviation Administration.

Bender, L. W. (1987). Iransfer and articulation ameng the public institutions of higher education in New Jersey. Tallahassee: Florida State University State \& Regional Higher Educational Center. ERIC \#ED283586.

Cessna integrated flight training system [Flight prep 1A]. (1974). Denver, CO.: Jeppensen and Company.

Kintzer, F. C., \& Wattenbarger, J. L. (1985). The articulation/transfer phenomenon. Patterns \& directions. Washington: American Association of Community and Junior Colleges.

Kintzer, F. C. (1983). The multidimensional problem of articulation and transfer [Report]. Los Angeles, CA: ERIC Clearinghouse for Junior Colleges.

Knoell, D. M., \& Medsker, L. L. (1964). Eactors affecting pentormance of transfer students from two- to four-year colleges: With implications for coordination and articulation. Berkeley, CA: University of California Center for Study of Higher Education.

Medsker, L. W. . (1960). The iunior college: Progress and prospect. New York: McGraw-Hill.

Oklahoma state regents for higher eduction policies and procedures. (1990, April). Oklahoma City, OK.

Palmer, J. (1986). Bolstering the community college transfer function. Washington: Office of Educational Research and Improvement.

Parnell, D. (1988, September). The future of the community college. Washington: American Association of Community and Junior Colleges.

Policies of senior colleges and universities concerning transfer students from two-year colleges in North Carolina [Report]. (1983). Chapel Hill, NC: North Carolina University.

University Aviation Association. (1976). College aviation accreditation quidelines. Wichita, KS: Beech Aircraft Corporation and Cessna Aircraft Company.

Walton, K. D. (1984). Articulation: Transfer agreements, minimum grades acceptable on transfer courses, and transferability of associate degrees. In Community/Junier College Quarterly (pp. 169-184). 